\title{
OS MODELOS DE MODERNIZAÇÃO DA PAISAGEM NA ZONA NORTE DO RIO DE JANEIRO
}

\section{Vera Regina Tângari}

Professora adjunta da Faculdade de Arquitetura e Urbanismo da UFRJ, doutora pela FAUUSP

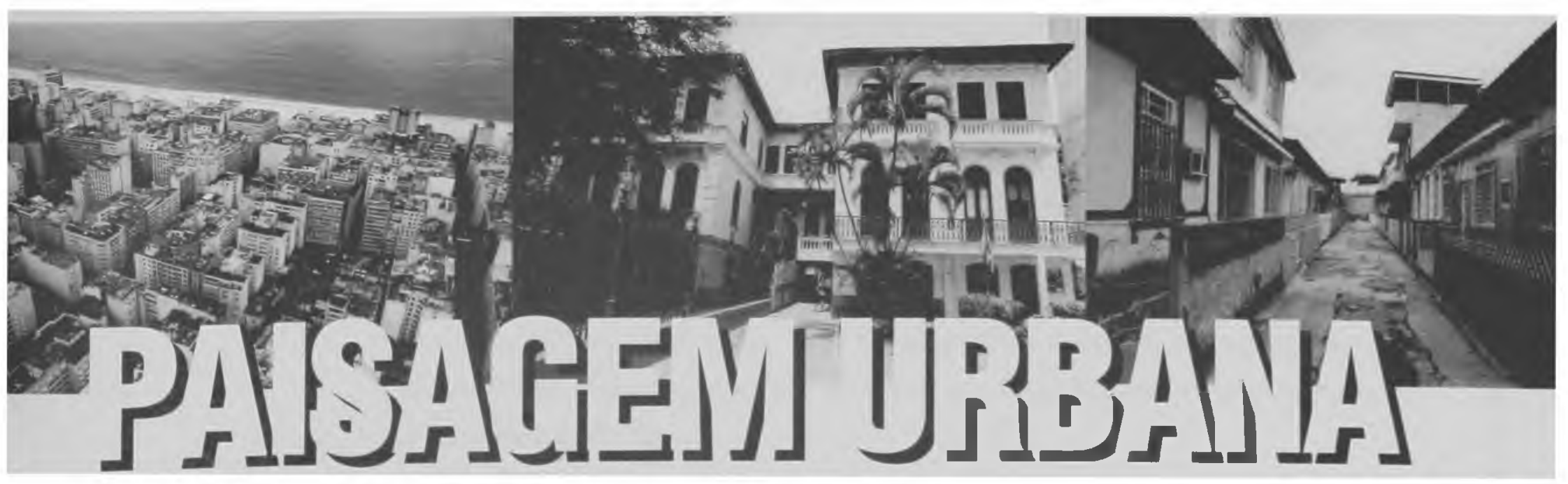




\section{RESUMO}

Este trabalho enfoca a paisagem urbana da cidade do Rio de Janeiro e busca estabelecer um corpo analítico sobre um tema central: os processos de reprodução dos padrōes de configuração da arquitetura da paisagem carioca das áreas centrais nas áreas periféricas, mais especificamente nos subúrbios ferroviários da zona norte da cidade.

Foi realizada a descrição do processo de modelização da paisagem suburbana, estabelecendo um elo de comparação entre os modelos gerais e os tipos específicos dos subúrbios.

O trabalho conclui sobre a adequação morfológica e ambiental dos tipos específicos ao contexto tropical do Rio de Janeiro e sugere possíveis reformulações na legislação urbanística, visando melhorar a qualidade ambiental e paisagística da região suburbana.

\section{ABSTRACT}

This thesis focus on Rio de Janeiro's urban landscape. It aims to form a methodological framework in order to deal with one central theme: the multiplication the central landscape architecture configuration patterns in the different areas of the city, focusing on the northern suburban neighborhoods, along the railway lines.

The analysis includes the description of the landscape modelling process in the suburban area, by comparing the city's general patterns and the local ones.

The paper also describes the morphological and environmental adequacy of the local types, as related to the tropical context of Rio de Janeiro, by suggesting the revision of the urban regulation codes, in order to increase the environmental and landscape quality of the railway suburban neighbourhood. 
A morfologia urbana, decorrência da modelização, foi expressa por elementos relacionados ao traçado urbano, à volumetria edificada, à relação entre os cheios e vazios, à presença da vegetação e das superfícies de água, indicando, desta maneira, as características peculiares da cidade do Rio de Janeiro e dos seus diversos ambientes.

Condicionada pela modelização da paisagem, a estética arquitetônica cumpriu papel importante na formação da imagem da cidade, tendo sido representada pelos seus diversos movimentos: o neoclassicismo, associado ao reinado, a belle époque e o ecletismo, vigentes desde o final do império até a virada do século, e o arranha-céu moderno, a partir da década de 30 do século 20, são exemplos de símbolos formais, constituindo-se em arquétipos de desenho adotados em todo o universo da cidade.

Como elemento importante no esforço de modernização do espaço urbano, destaca-se o projeto dos espaços livres públicos, por incorporar as inovações que, vindas do exterior, foram implantadas nos bairros mais valorizados da cidade, constituindo-se em modelos de reprodução interna e compondo o patrimônio paisagístico oficial.

Quando transplantados para situações diversas, apresentados pelos bairros em que se divide a cidade, os modelos de desenho da paisagem, sofreram, pela redução ou adaptação, modificações que possibilitaram sua reprodução e ampla utilização no universo urbano.

O quadro a seguir apresenta os principais processos de modelização da paisagem do Rio de Janeiro e seus ícones, verificados como padrōes gerais da cidade e como tipos locais da zona norte e dos subúrbios ferroviários enfocados.

\section{Tipos de configuração morfológica dos subúrbios e os padrões de estética urbana gerais}

\begin{tabular}{l|l|l|l}
\hline \multicolumn{1}{c|}{ Modelo } & \multicolumn{1}{c|}{ Padrão Geral } & \multicolumn{1}{c|}{ Tipo Local } & \multicolumn{1}{c}{$\begin{array}{c}\text { Processo de } \\
\text { Modelização }\end{array}$} \\
\hline $\begin{array}{l}\text { Urbanismo colonial } \\
\text { Traçado em tabuleiro } \\
\text { Arquitetura eclética }\end{array}$ & $\begin{array}{l}\text { Quadra portuguesa - } \\
\text { casas térreas e sobrados } \\
\text { geminados }\end{array}$ & Arquitetura da ferrovia & Adaptação \\
\hline $\begin{array}{l}\text { Período: século 17 a 2a } \\
\text { metade do século 19 }\end{array}$ & $\begin{array}{l}\text { Período: século 17 a 2a } \\
\text { metade do século 19 }\end{array}$ & $\begin{array}{l}\text { Período: 2a metade do } \\
\text { século 19 a 2a década } \\
\text { do século 20 }\end{array}$ & \\
\hline
\end{tabular}




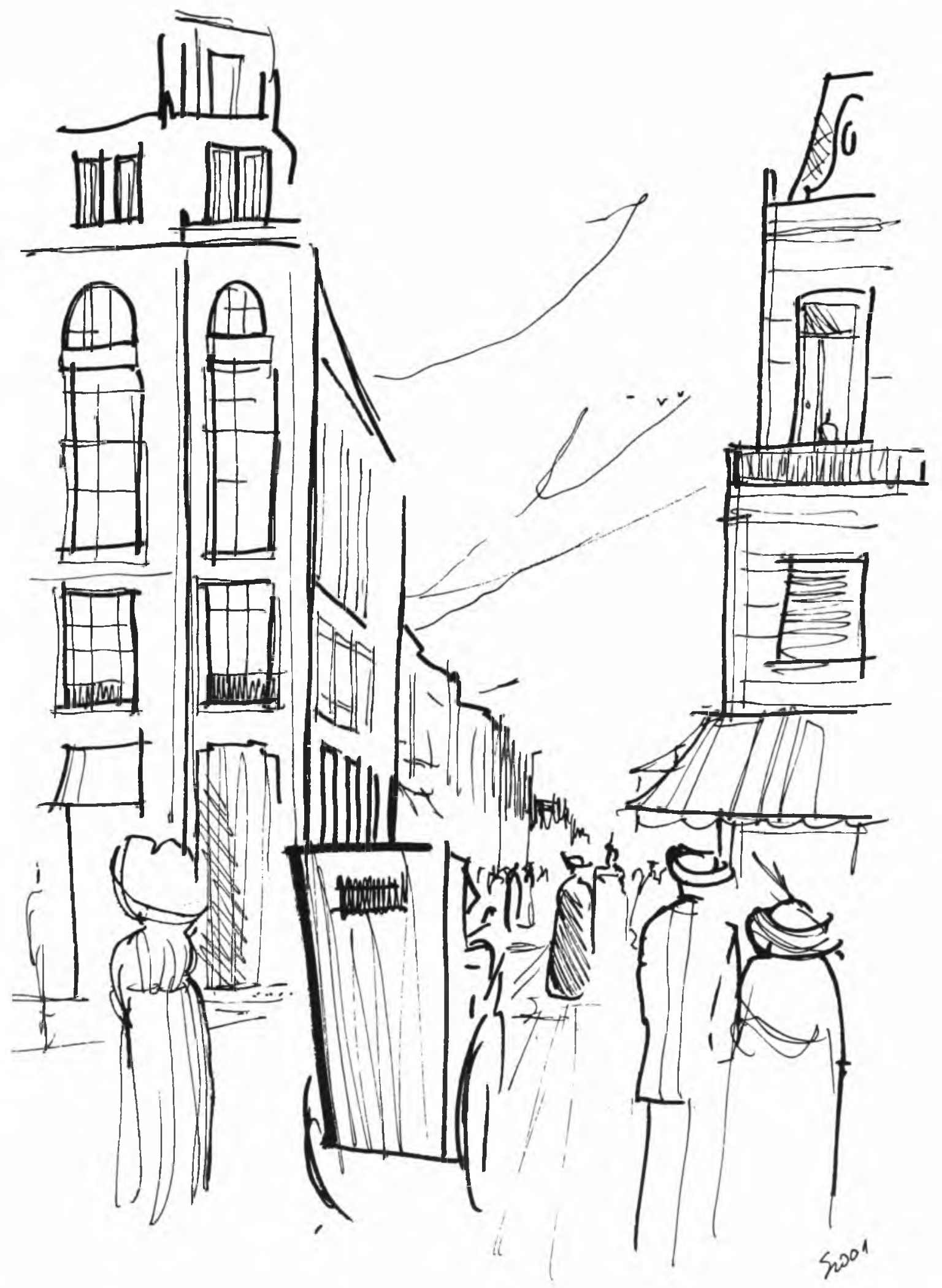

Rua Sete de

Setembro, em 1907

Fonte: PCRJ, 1998

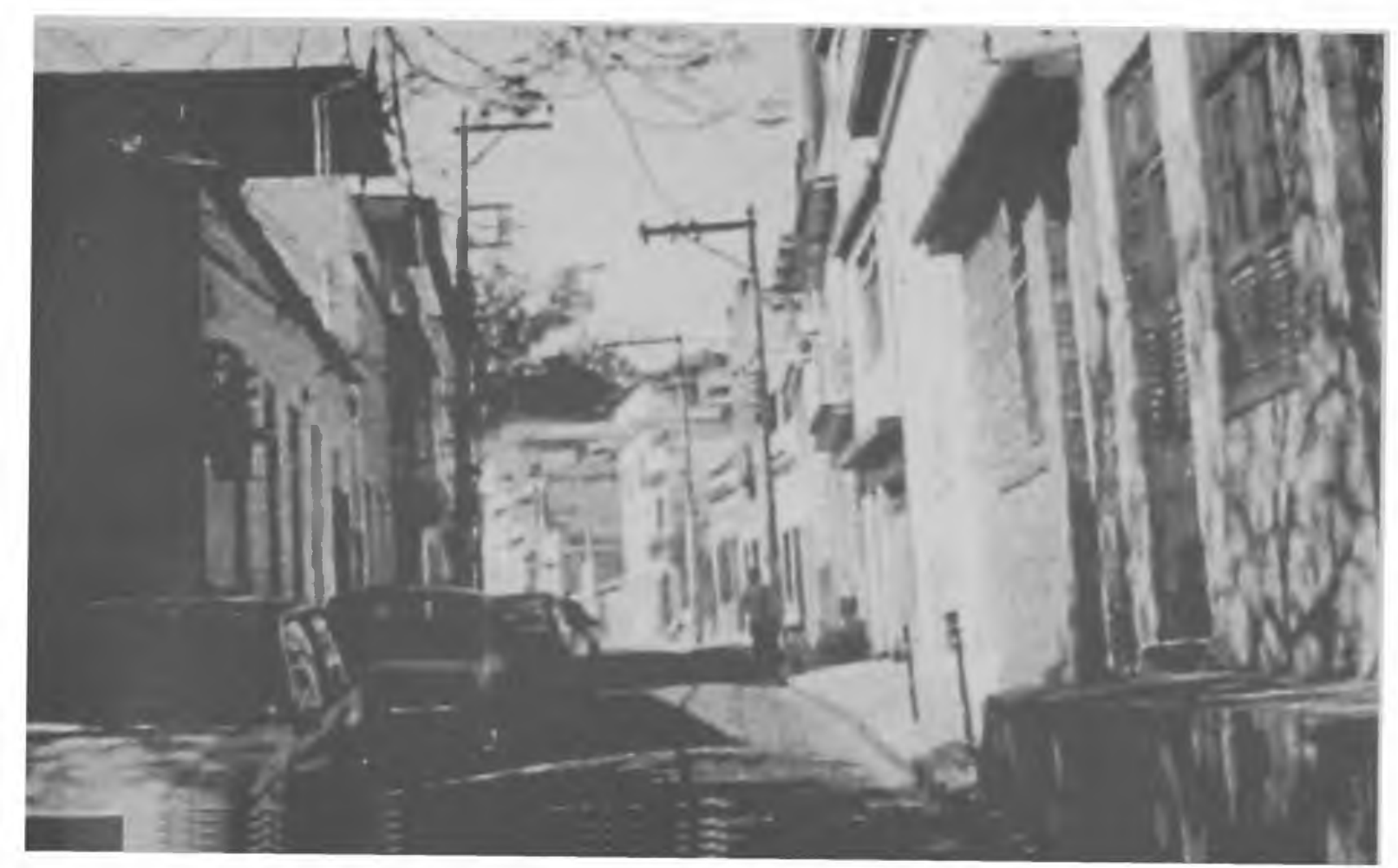

Casario eclético,

Morro da

Conceição, centro.

Fonte: Foto do autor, 2001 
Casario na rua 24 de Maio,

junto à linha

férrea, no Meier

Fonte: Foto de

Marcos London,

1999 - Arquivo

PUZN

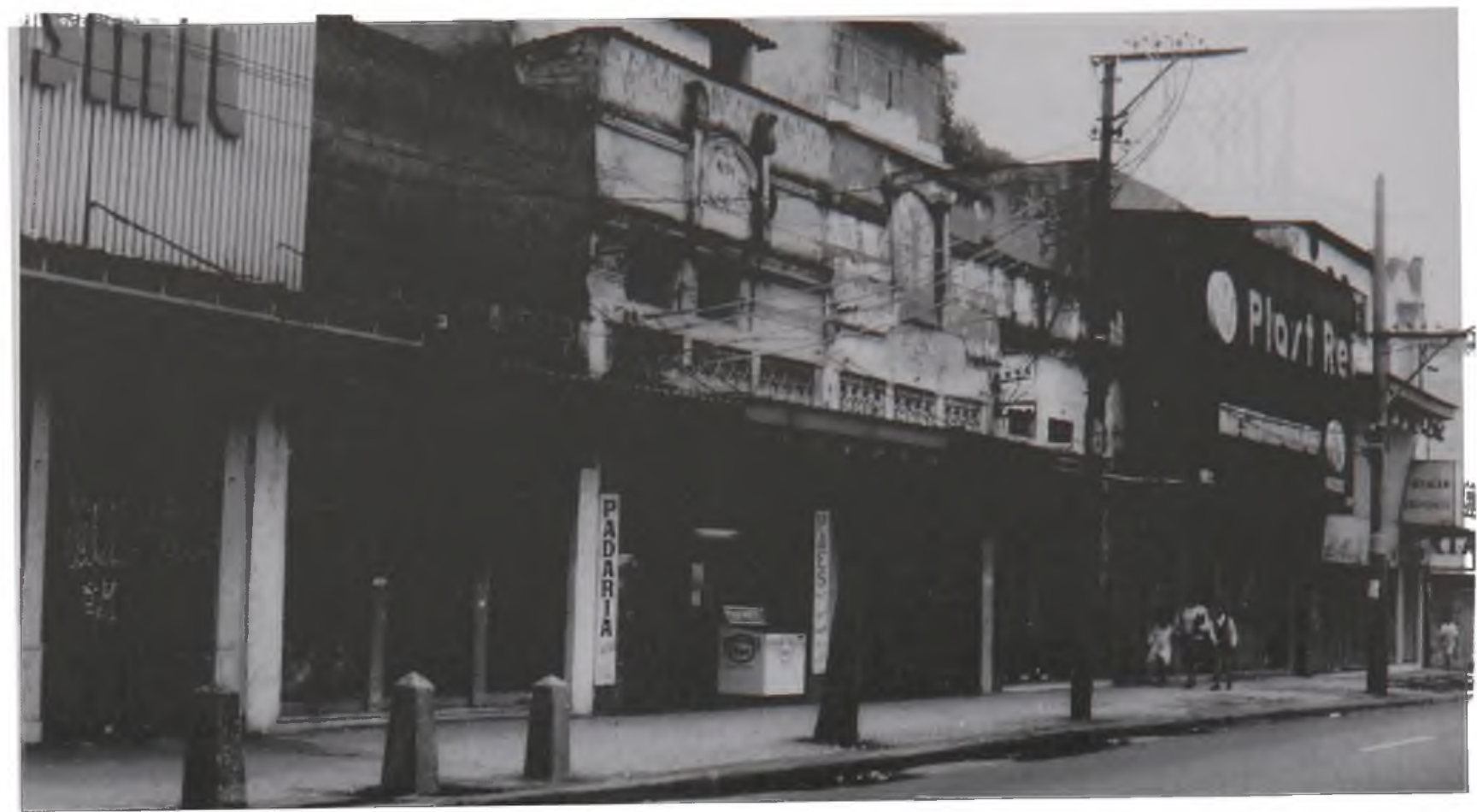

\begin{tabular}{|c|c|c|c|}
\hline Modelo & Padrão Geral & Tipo Local & $\begin{array}{l}\text { Processo de } \\
\text { Modelizaçāo }\end{array}$ \\
\hline $\begin{array}{l}\text { Urbanismo colonial } \\
\text { Traçado em tabuleiro } \\
\text { Arquitetura eclética }\end{array}$ & $\begin{array}{l}\text { Quadra portuguesa - } \\
\text { casas térreas e sobrados } \\
\text { geminados }\end{array}$ & Vila residencial & Adaptação \\
\hline $\begin{array}{l}\text { Período: } 2^{\circ} \text { metade do } \\
\text { século } 19 \text { a } 2^{a} \text { década } \\
\text { do século } 20\end{array}$ & $\begin{array}{l}\text { Período: } 2 \text { a metade do } \\
\text { século } 19 \text { a meados do } \\
\text { século } 20\end{array}$ & $\begin{array}{l}\text { Período: } 2 \text { o metade do } \\
\text { século } 19 \text { a meados do } \\
\text { século } 20\end{array}$ & \\
\hline
\end{tabular}

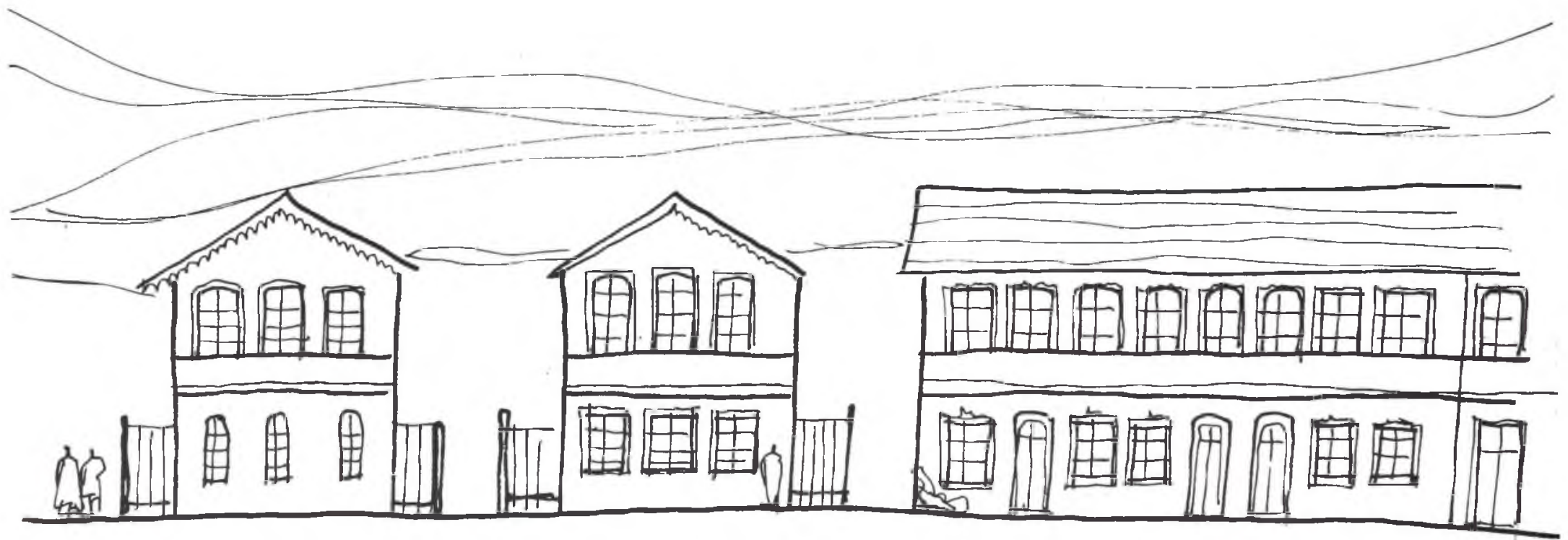

Projeto de vila operária do engenheiro Vieira Souto

Fonte: Vaz, 1994 


\begin{tabular}{l|l|l|l}
\hline \multicolumn{1}{c|}{ Modelo } & \multicolumn{1}{|c|}{ Padrão Geral } & \multicolumn{1}{c}{ Tipo Local } & \multicolumn{1}{c}{$\begin{array}{c}\text { Processo de } \\
\text { Modelizaçáo }\end{array}$} \\
\hline $\begin{array}{l}\text { Urbanismo colonial } \\
\text { Traçado em tabuleiro } \\
\text { Arquitetura eclética }\end{array}$ & $\begin{array}{l}\text { Quadra portuguesa - } \\
\text { casas térreas e sobrados } \\
\text { geminados }\end{array}$ & $\begin{array}{l}\text { Casas geminadas e } \\
\text { correr de casas }\end{array}$ & Adaptação \\
\hline $\begin{array}{l}\text { Período: 2a metade do } \\
\text { século 19 a início do } \\
\text { século 20 }\end{array}$ & $\begin{array}{l}\text { Período: 2a metade do } \\
\text { século 19 a início do } \\
\text { século 20 }\end{array}$ & $\begin{array}{l}\text { Período: 2o metade do } \\
\text { século 19 a meados do } \\
\text { século 20 }\end{array}$ & \\
\hline
\end{tabular}

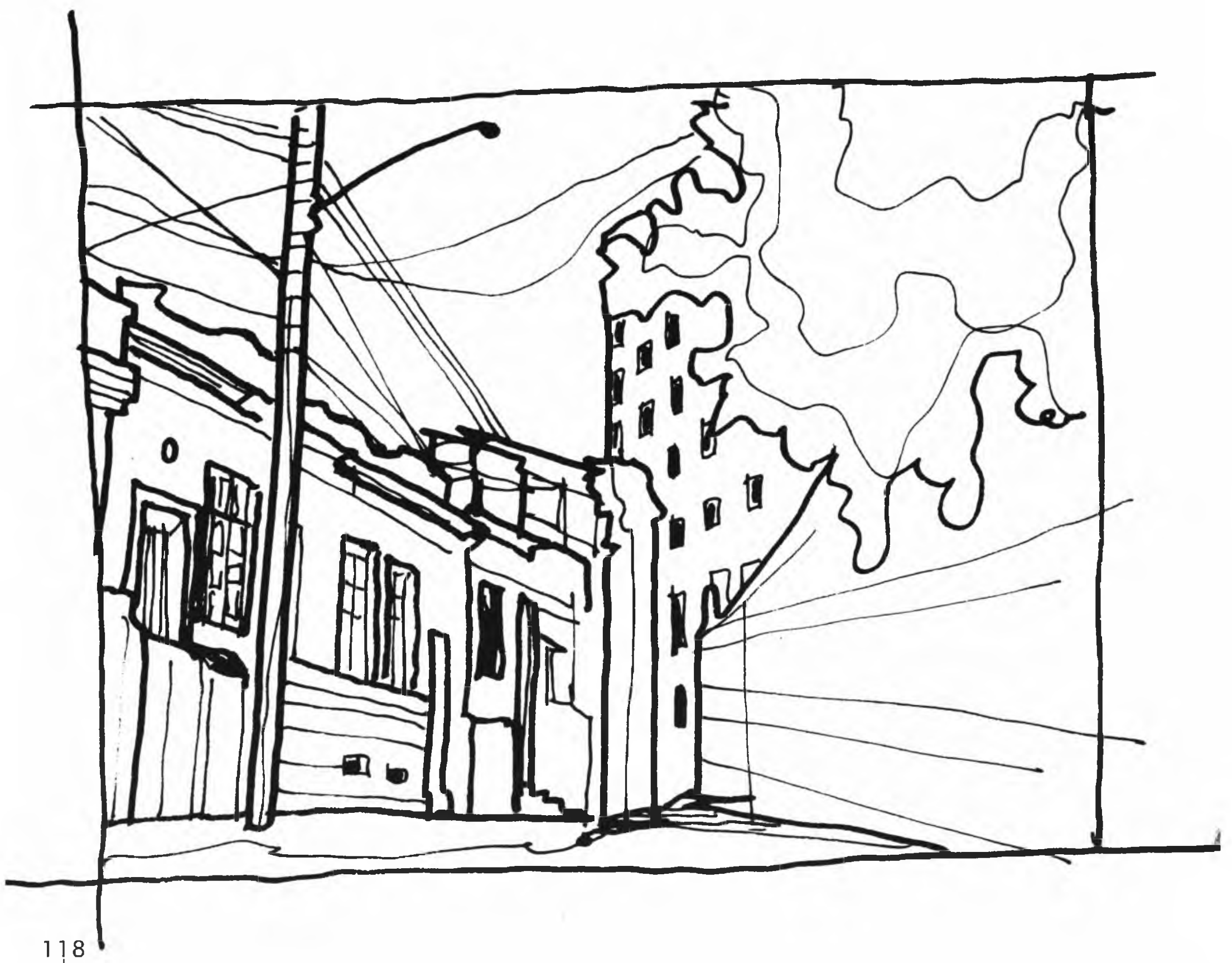

Casas geminadas na Ladeira da Pedra do Sal, na Saúde Fonte: Foto da autora, 2001 


\begin{tabular}{l|l|l|l}
\hline \multicolumn{1}{c|}{ Modelo } & \multicolumn{1}{c|}{ Padrāo Geral } & \multicolumn{1}{c}{ Tipo Local } & \multicolumn{1}{c}{$\begin{array}{c}\text { Processo de } \\
\text { Modelização }\end{array}$} \\
\hline $\begin{array}{l}\text { Urbanismo colonial } \\
\text { Traçado em tabuleiro } \\
\text { ou adaptado ao } \\
\text { terreno } \\
\begin{array}{l}\text { Urbanismo romântico, } \\
\text { padrão inglês } \\
\text { Arquitetura colonial, } \\
\text { eclética e art déco }\end{array}\end{array}$ & $\begin{array}{l}\text { Quadra portuguesa com } \\
\text { chácaras urbanas } \\
\text { Quadra cidade - jardim } \\
\text { inglesa - chalés, mini- } \\
\text { palacetes, com } \\
\text { arquitetura art déco }\end{array}$ & $\begin{array}{l}\text { Palacetes reduzidos e } \\
\text { chácaras urbanas }\end{array}$ & Redução \\
\hline $\begin{array}{l}\text { Período: século 19 a } \\
\text { início do século 20 }\end{array}$ & $\begin{array}{l}\text { Período: século 19 a } \\
\text { início do século 20 }\end{array}$ & Período: século 19 a 2a \\
década do século 20 & \\
\hline
\end{tabular}

Palacete na rua São Clemente, Botafogo, atual casa de Rui Barbosa Fonte: Foto de Marcos London - Arquivo PUZN

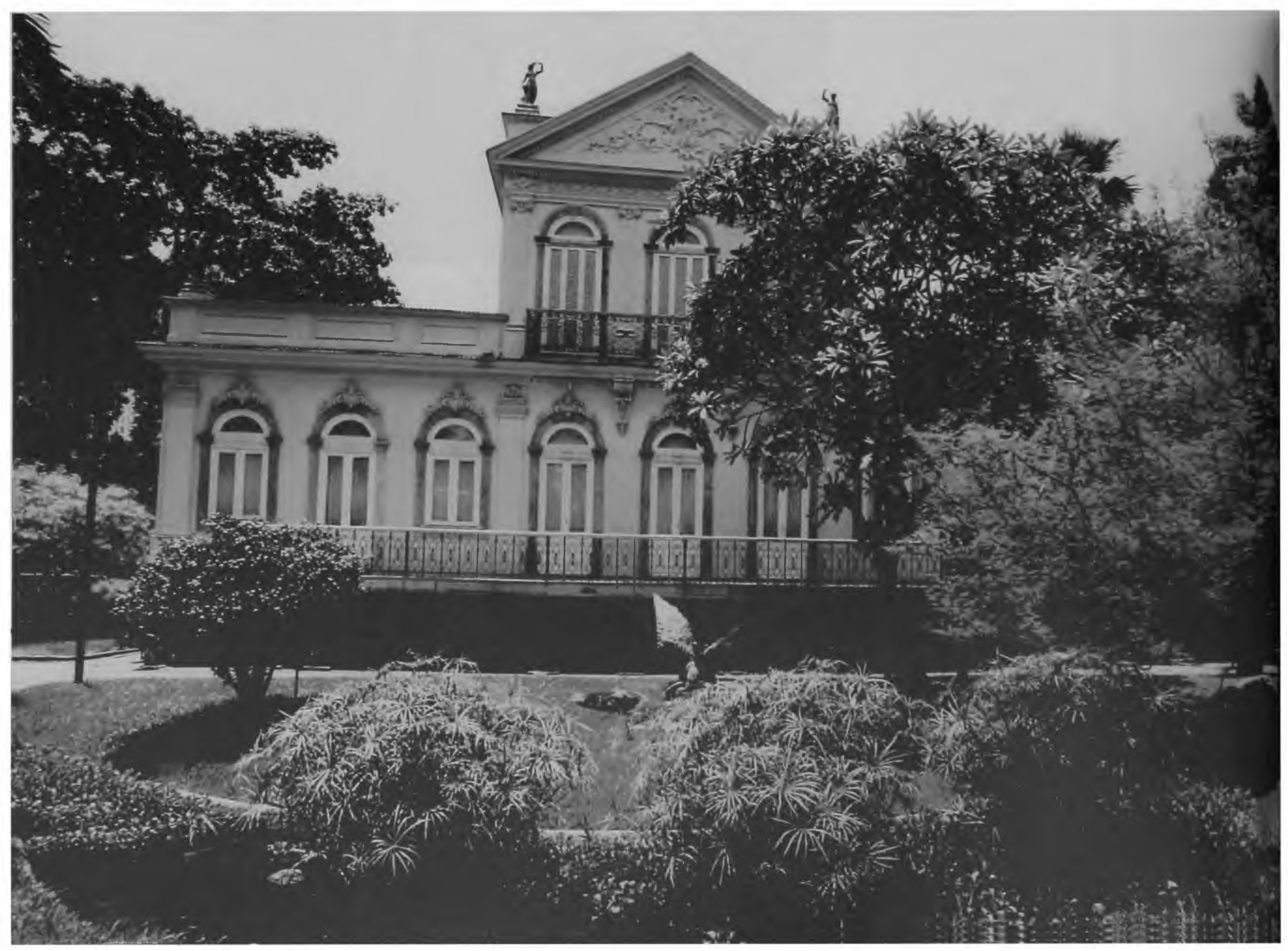


Mini palacete ant déco em Piedade Fonte: Foto de M\&T, Arquivo Concurso PEU, Méier

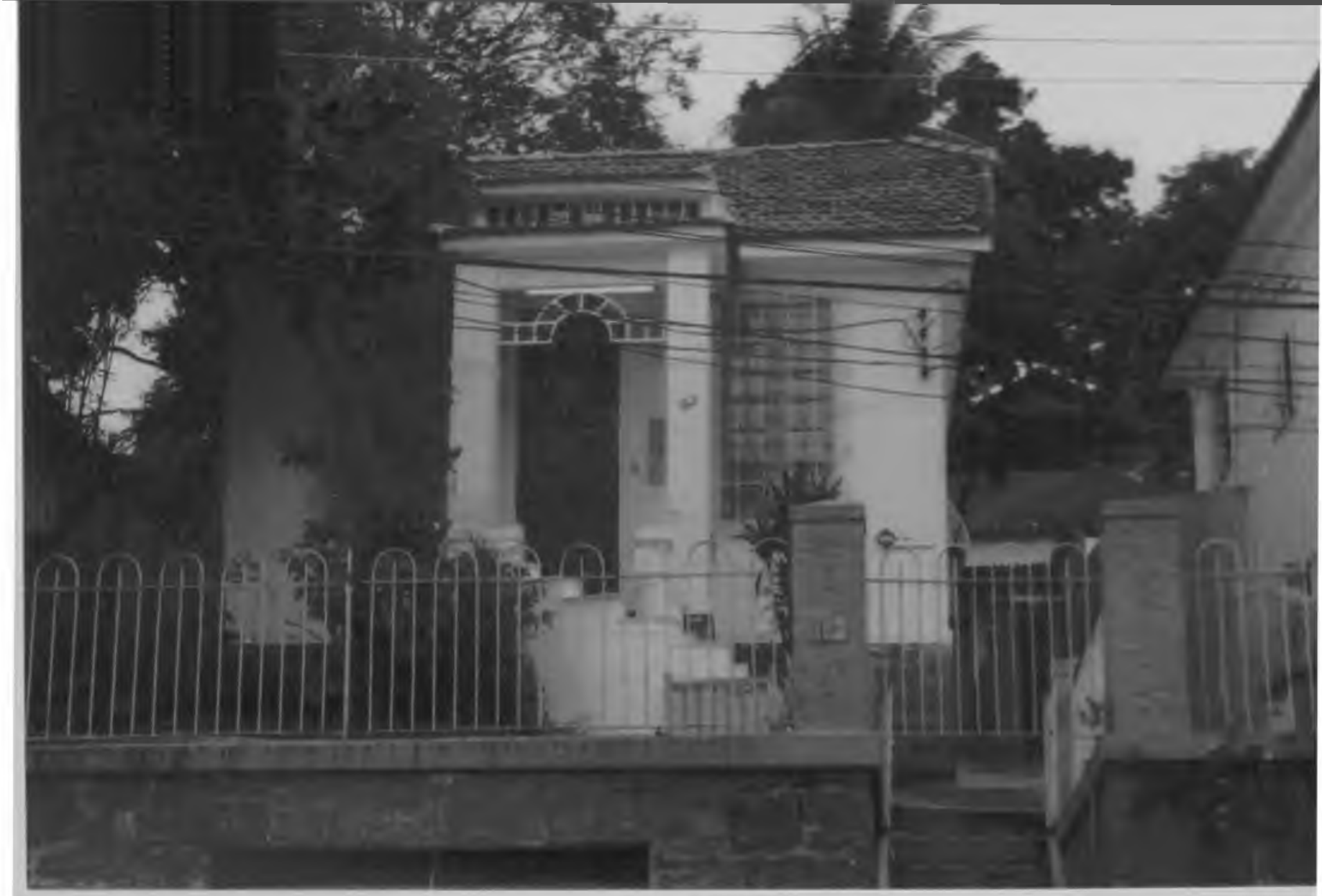

Solores na rua Cosme Velho, Cosme Velho

Fonte: Foto de Marcos London - Arquivo PUZN

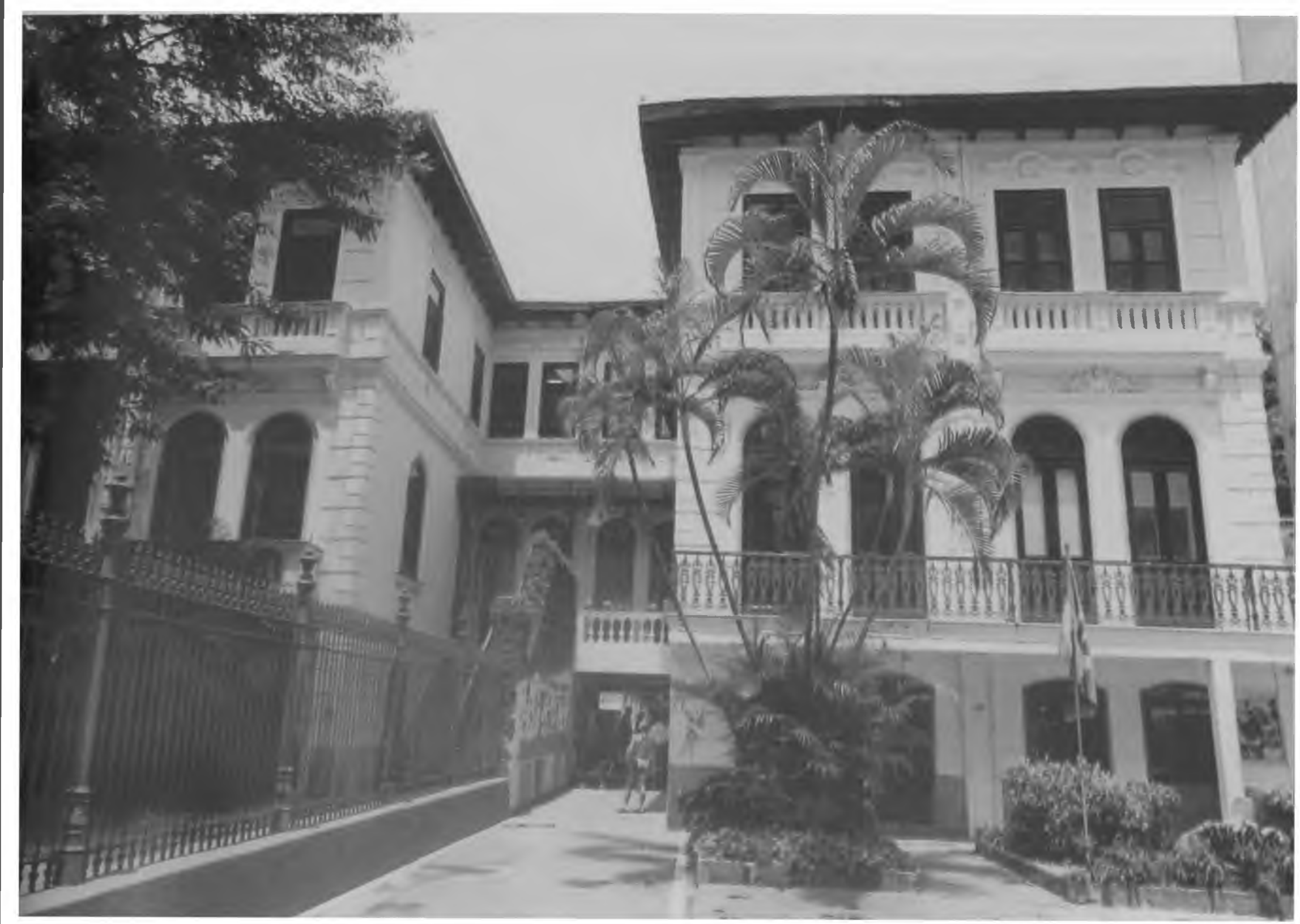




\begin{tabular}{|c|c|c|c|}
\hline Modelo & Padrão Geral & Tipo Local & $\begin{array}{l}\text { Processo de } \\
\text { Modelização }\end{array}$ \\
\hline $\begin{array}{l}\text { Urbanismo colonial } \\
\text { Traçado em tabuleiro } \\
\text { Urbanismo romântico, } \\
\text { padrão inglês } \\
\text { Arquitetura colonial, } \\
\text { eclética e art déco }\end{array}$ & $\begin{array}{l}\text { Quadra portuguesa - } \\
\text { casas térreas e sobrados } \\
\text { isolados }\end{array}$ & $\begin{array}{l}\text { Palacetes isolados no } \\
\text { lote }\end{array}$ & Adaptação \\
\hline Período: séculos 19 e 20 & Período: séculos 19 e 20 & $\begin{array}{l}\text { Período: } 2^{a} \text { metade } \\
\text { século } 19 \text { ao século } 20\end{array}$ & \\
\hline
\end{tabular}

Casa no Cosme Velho

Fonte: Foto de Marcos London, 1999 - Arquivo PUZN

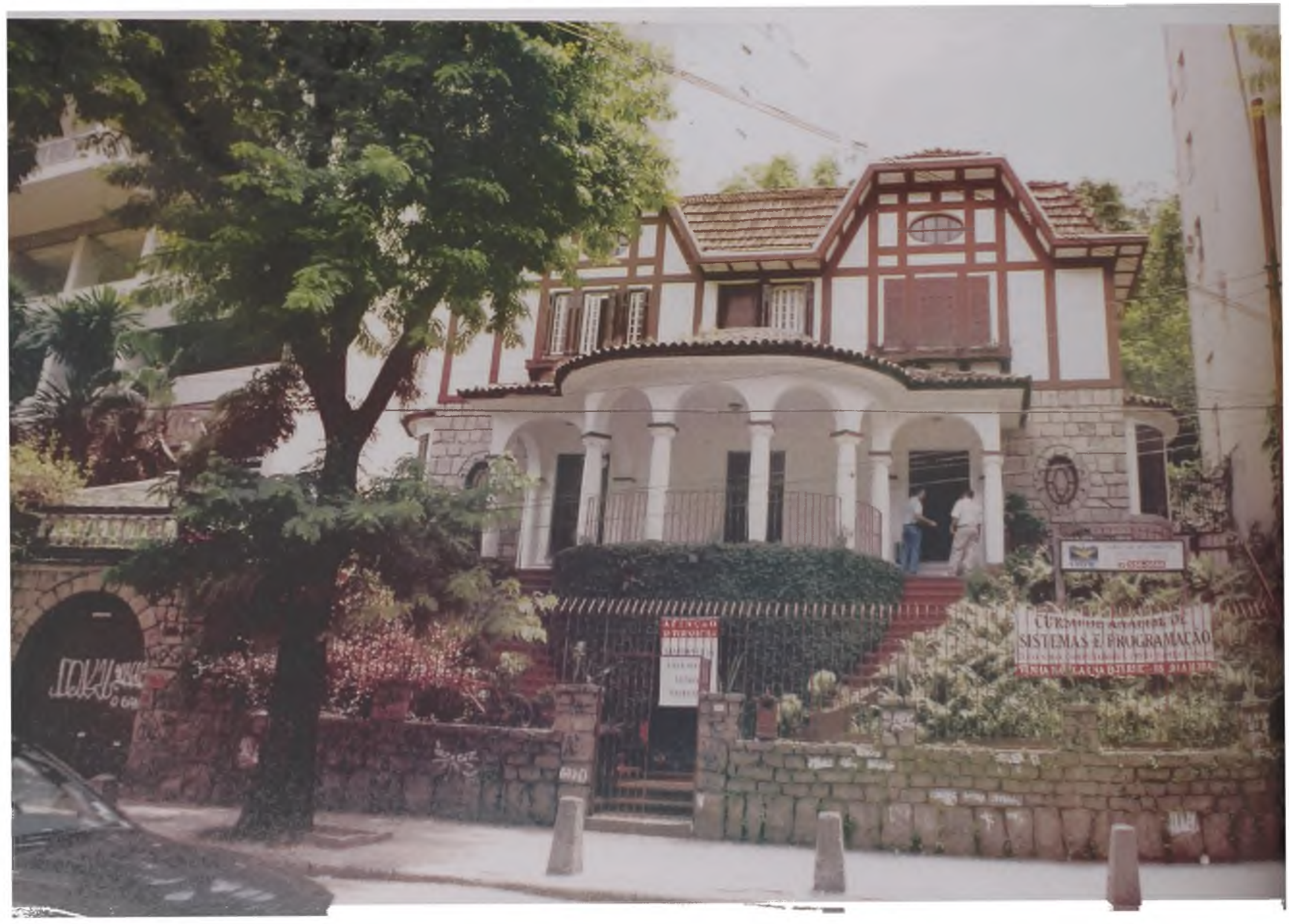




\begin{tabular}{l|l|l|l}
\hline \multicolumn{1}{c|}{ Modelo } & \multicolumn{1}{c|}{ Padrão Geral } & Tipo Local & \multicolumn{1}{c}{$\begin{array}{c}\text { Processo de } \\
\text { Modelização }\end{array}$} \\
\hline $\begin{array}{l}\text { Urbanismo clássico } \\
\text { europeu } \\
\begin{array}{l}\text { Traçado francês com } \\
\text { edifícios baixos }\end{array}\end{array}$ & $\begin{array}{l}\text { Quadra trancesa com } \\
\text { prédios na transição } \\
\text { para o modernismo }\end{array}$ & Prédios baixos & Adaptação/redução \\
\hline $\begin{array}{l}\text { Período: início da 3a } \\
\text { década do século 20 }\end{array}$ & $\begin{array}{l}\text { Período: início da 3a } \\
\text { década do século 20 }\end{array}$ & $\begin{array}{l}\text { Período: 3a a 5a décadas } \\
\text { do século 20 }\end{array}$ & \\
\hline
\end{tabular}

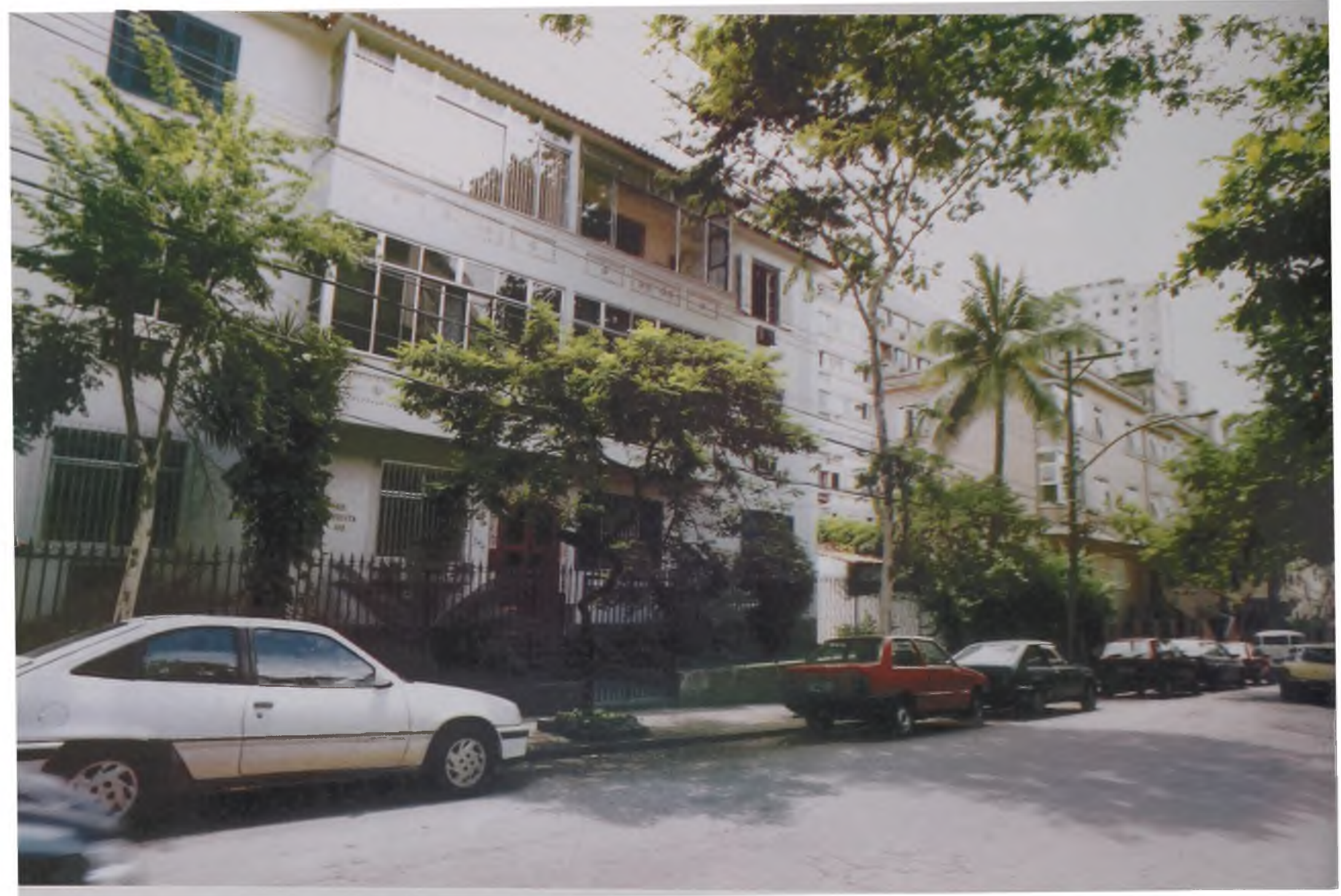

Prédio de

três pavimentos,

em Laranjeiras

Fonte: Foto de Marcos

London, 1999 .

Arquivo PUZN 


\begin{tabular}{l|l|l|l}
\hline \multicolumn{1}{c|}{ Modelo } & \multicolumn{1}{c|}{ Padrão Geral } & \multicolumn{1}{c}{ Tipo Local } & \multicolumn{1}{c}{$\begin{array}{c}\text { Processo de } \\
\text { Modelização }\end{array}$} \\
\hline $\begin{array}{l}\text { Urbanismo moderno } \\
\begin{array}{l}\text { Traçado urbano francês } \\
\text { com edifícios altos }\end{array}\end{array}$ & $\begin{array}{l}\text { Quadra - blocos } \\
\text { francesa com edifícios } \\
\text { altos }\end{array}$ & Edifícios modernos & Adaptação \\
\hline $\begin{array}{l}\text { Período: a partir da 3a } \\
\text { década do século 20 }\end{array}$ & $\begin{array}{l}\text { Período: a partir da 3a } \\
\text { década do século 20 }\end{array}$ & $\begin{array}{l}\text { Período: a partir da 5a } \\
\text { década até o final do } \\
\text { século 20 }\end{array}$ & \\
\hline
\end{tabular}

Quadras em Copacabana

Fonte: Foto de Silvio Macedo, 1999 - Arquivo PUZN

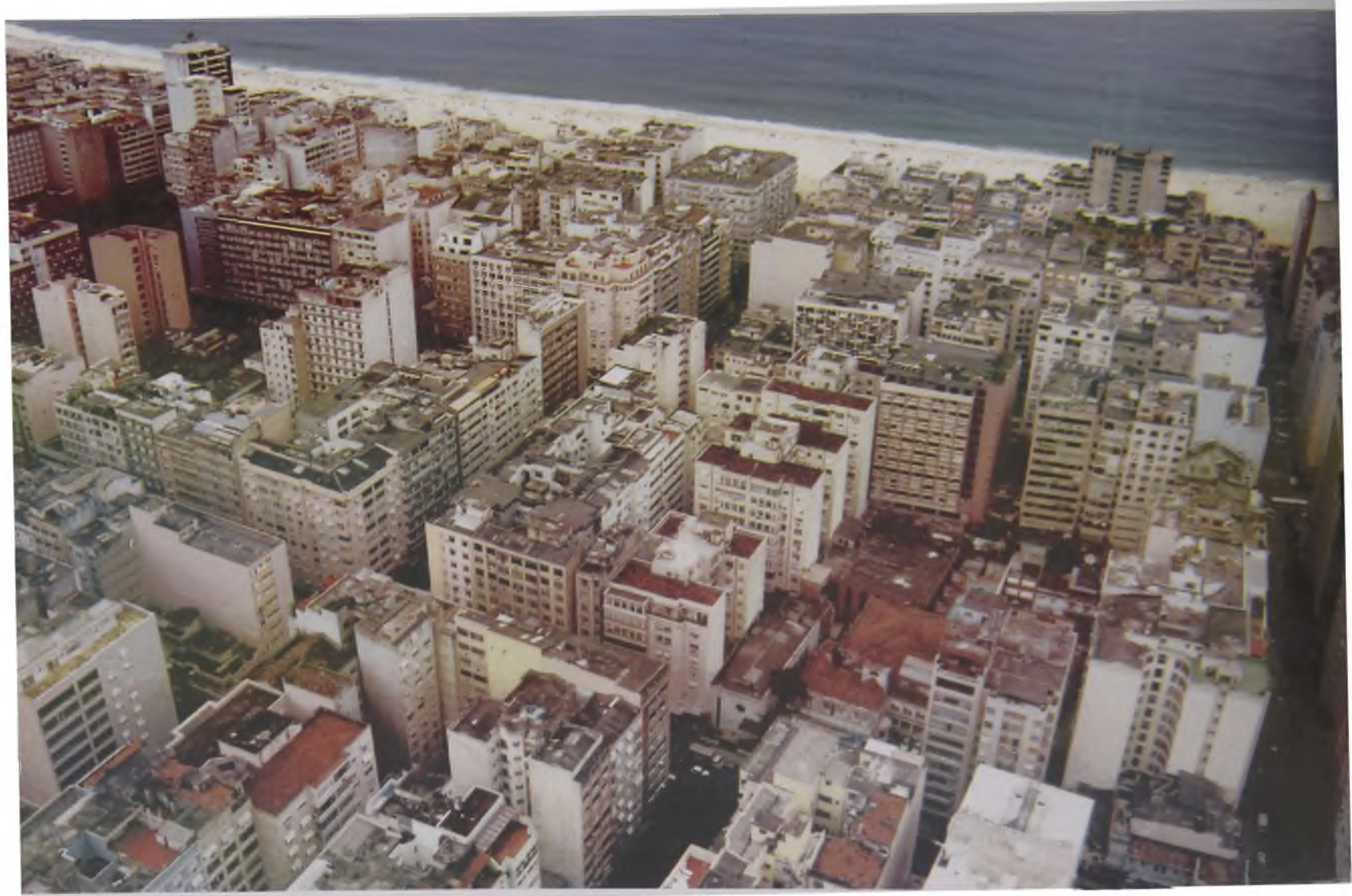




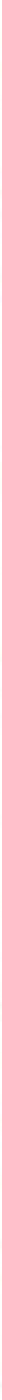

Edifícios na rua Conde de Bonfim, na Tijuca

Fonte: Foto de Marcos London, 1999 - Arquivo PUZN

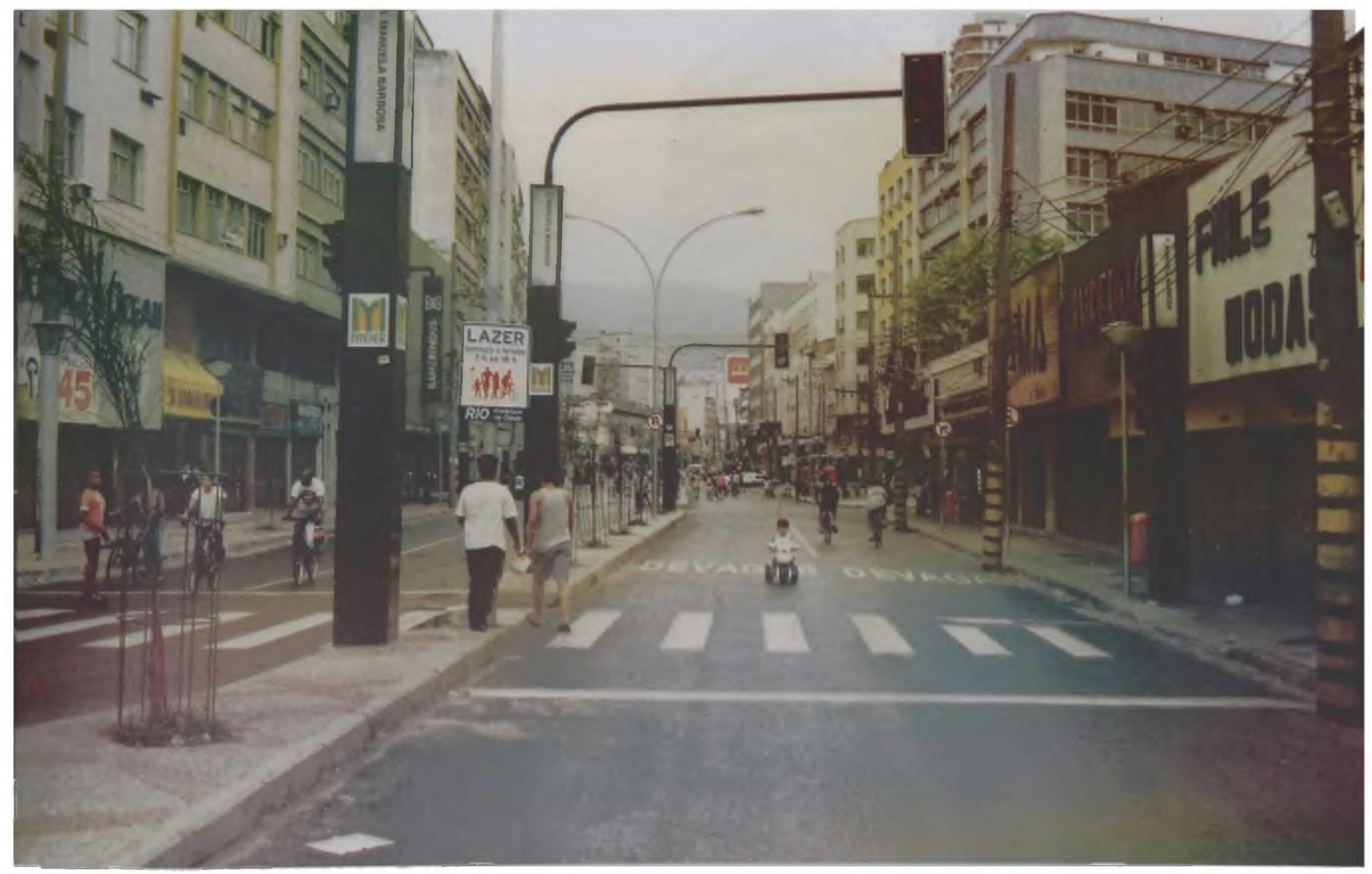

Edificios na rua Dias da Cruz, no Méier

Fonte: Foto de Silvio Macedo, 1996 


\begin{tabular}{l|l|l|l}
\hline \multicolumn{1}{c|}{ Modelo } & \multicolumn{1}{c|}{ Padrāo Geral } & Tipo Local & \multicolumn{1}{c}{$\begin{array}{c}\text { Processo de } \\
\text { Modelização }\end{array}$} \\
\hline $\begin{array}{l}\text { Urbanismo modernista } \\
\text { Superquadra com } \\
\text { edifícios-torre }\end{array}$ & $\begin{array}{l}\text { Traçado francês com } \\
\text { torre isolada e } \\
\text { embasamento }\end{array}$ & Torres isoladas no lote & Reprodução \\
\hline $\begin{array}{l}\text { Período: a partir da 6ª e } \\
7 \text { décadas do século 20 }\end{array}$ & $\begin{array}{l}\text { Período: a partir da 6ª e } \\
7 \text { a décadas do século 20 }\end{array}$ & $\begin{array}{l}\text { Período: a partir da 7a } \\
\text { década do século 20 }\end{array}$ & \\
\hline
\end{tabular}

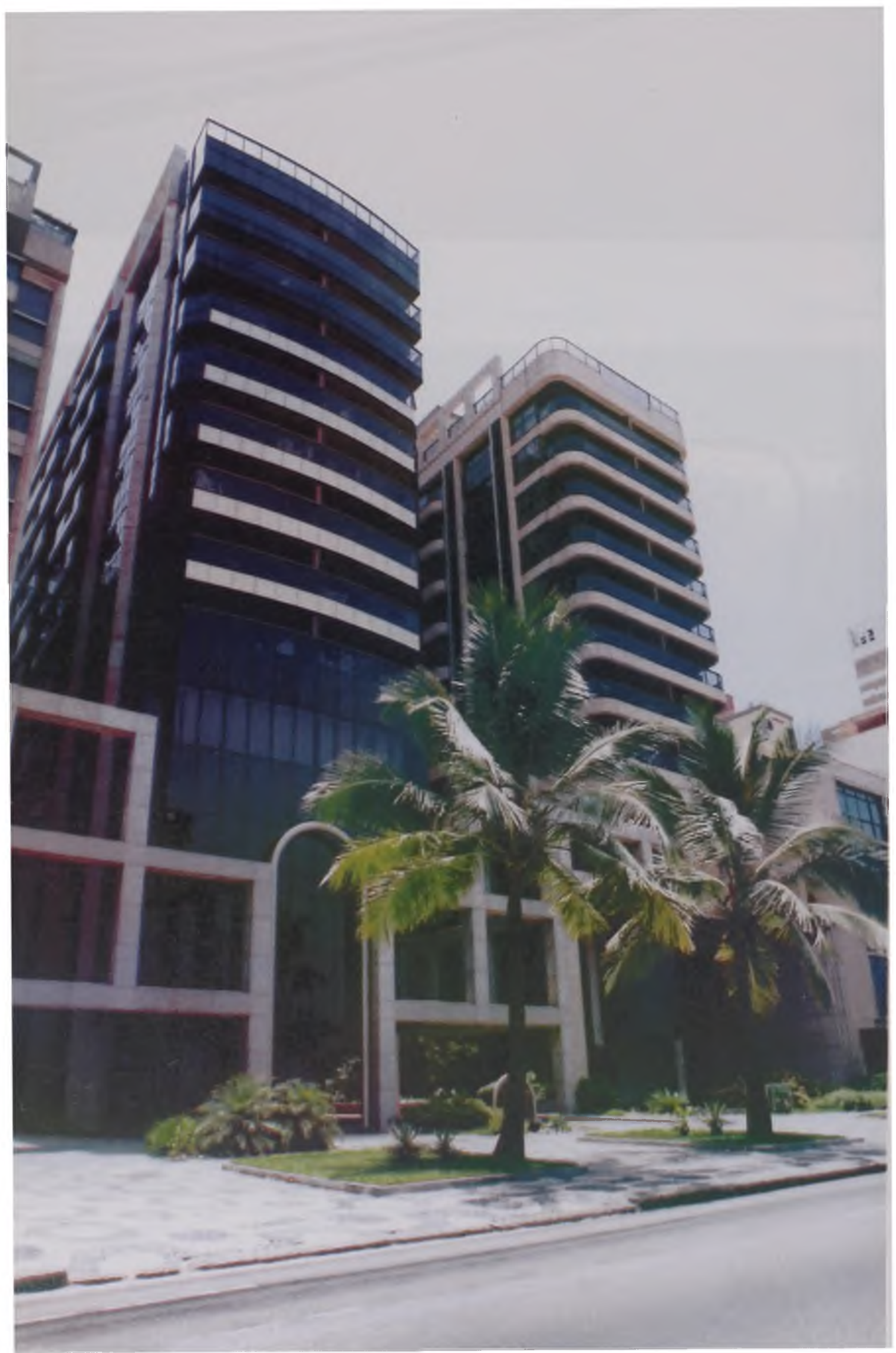

Conjunto de edifícios, em lpanema Fonte: Foto de Marcos London, 1999 - Arquivo PUZN 


\begin{tabular}{|c|c|c|c|}
\hline Modelo & Padrão Geral & Tipo Local & $\begin{array}{l}\text { Processo de } \\
\text { Modelização }\end{array}$ \\
\hline $\begin{array}{l}\text { Utopia modernista } \\
\text { Padronização } \\
\text { a rquitetônica }\end{array}$ & $\begin{array}{l}\text { Conjunto habitacional } \\
\text { com blocos isolados na } \\
\text { quadra }\end{array}$ & Conjuntos habitacionais & Reprodução \\
\hline $\begin{array}{l}\text { Período: } 6^{a} \text { e } 7^{a} \text { décadas } \\
\text { do século } 20\end{array}$ & $\begin{array}{l}\text { Período: } 6^{\circ} \text { e } 7^{0} \text { décadas } \\
\text { do século } 20\end{array}$ & $\begin{array}{l}\text { Período: } 6^{a} \text { e } 7^{\text {a }} \text { décadas } \\
\text { do século } 20\end{array}$ & \\
\hline
\end{tabular}

Conjunto em Jacarepaguá

Fonte: Foto de Silvio Macedo, 1999 - Arquivo PUZN

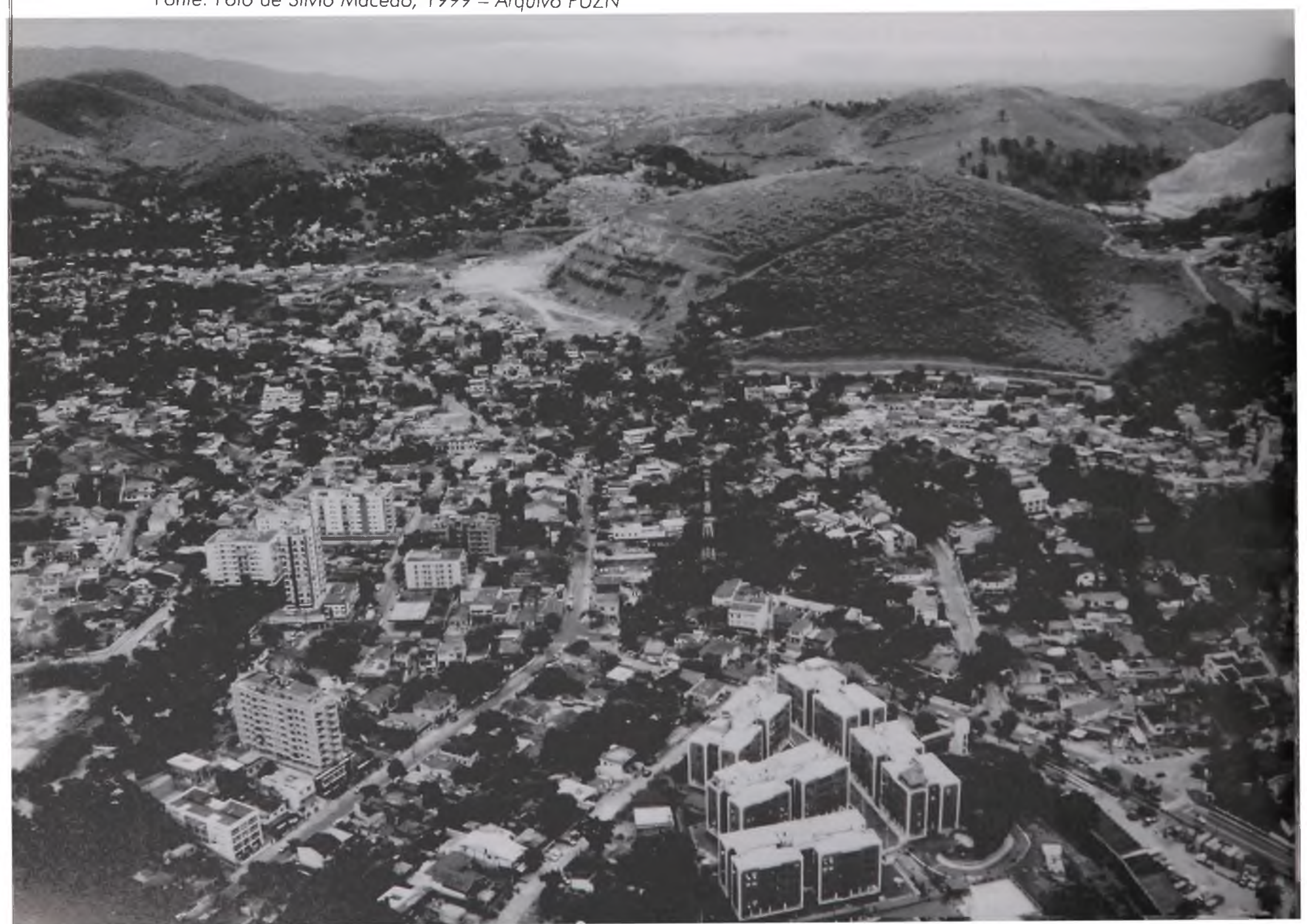


ray

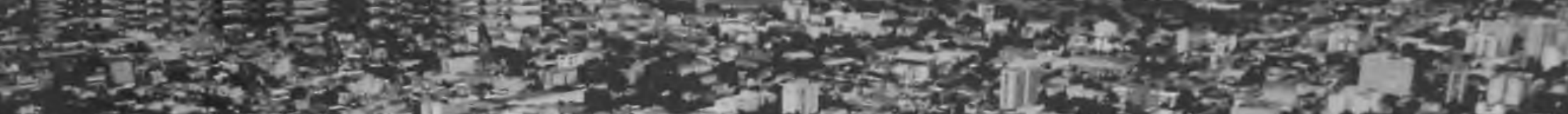
t5 s.

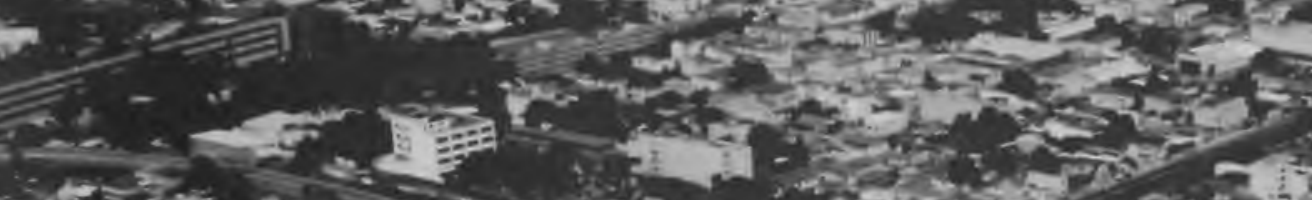

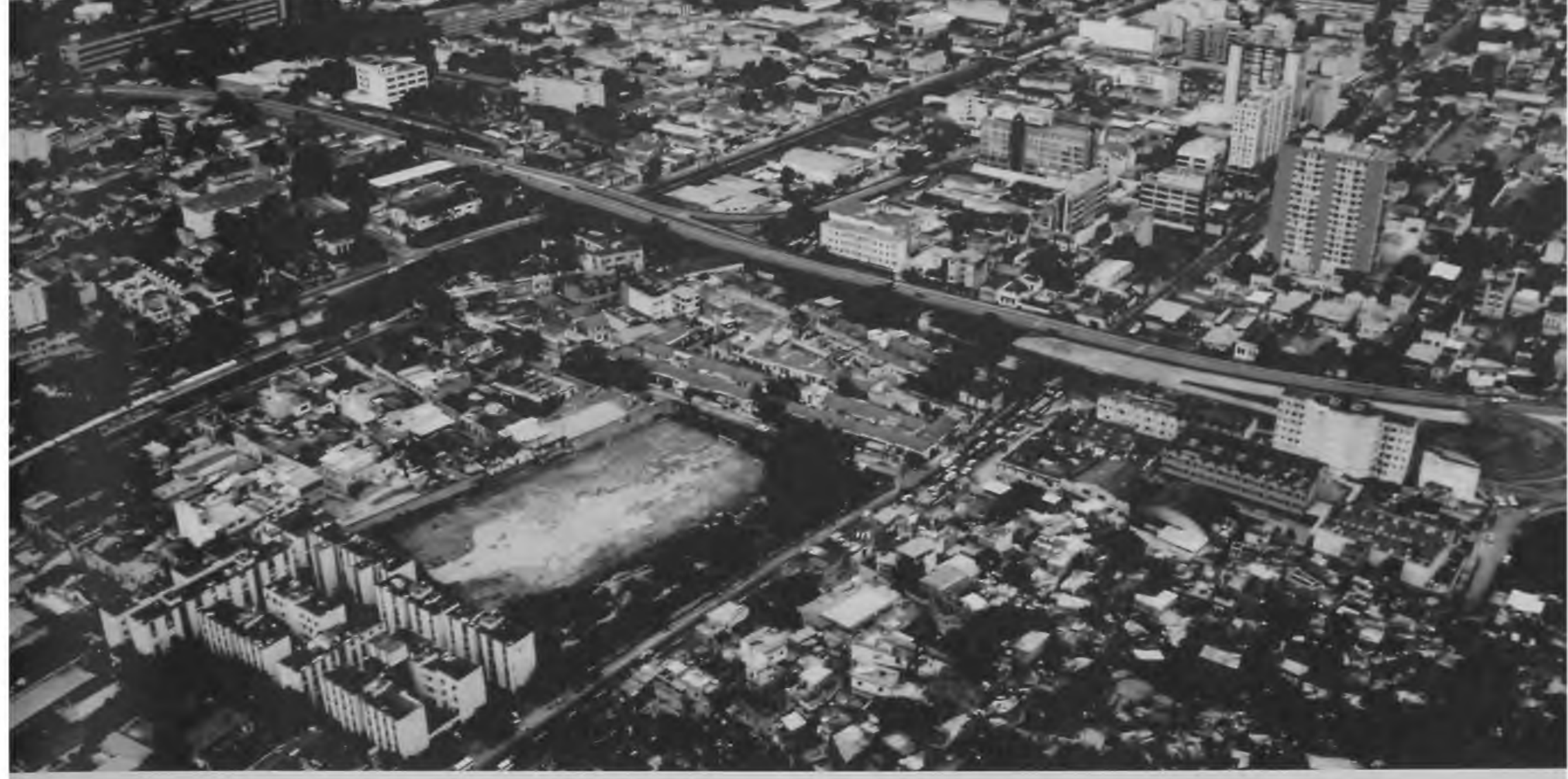

Conjunto do Engenho Novo

Fonte: Foto de Silvio Macedo, 1999 - Arquivo PUZN

Conjunto em Piedade

Fonte: Foto de Marcos London, 1999 - Arquivo PUZN

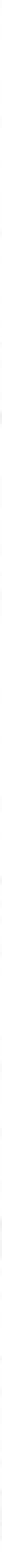


Os tipos de configuração estética e volumétrica, observados no século 19 e início desse século ("arquitetura da ferrovia", "vilas residenciais", "correr de casas e casas geminadas", e "palacetes e chácaras urbanas"), seguiram os modelos centrais, implantados nas áreas mais valorizadas da cidade, guardando, geralmente, certo distanciamento no tempo, decorrente da urbanização posterior dos subúrbios.

Os processos, nesses casos, foram de adaptação e redução de padrões gerais, refletidos na estrutura da cidade como um todo.

A partir de meados do século, a reprodução dos padrões gerais, decorrentes da transição da volumetria da cidade colonial para a cidade moderna ("casas isoladas", "prédios baixos" e "edifícios modernos"), passaram a indicar curtas distâncias no tempo entre a sua utilização nos bairros centrais e na zona sul, e a sua adaptação para tipos específicos dos subúrbios.

Finalmente, os padrões de volumetria modernista ("torres isoladas no lote" e "conjuntos habitacionais") foram utilizados praticamente em toda a cidade, ao mesmo tempo, encontrando-se exemplos nos diversos bairros do Rio, independentemente de sua localização.

Razões prováveis dessa maior padronização e reprodução de modelos foram decorrentes da aplicação da legislação urbanística, promulgada na década de 70, pelo decreto de zoneamento, e o próprio estágio de urbanização dos bairros, que, no caso dos subúrbios, experimentou, nesse período, as fases de consolidação urbana e valorização imobiliária de seus principais subcentros funcionais, como Méier e Madureira.

\section{Adequação Morfológica e Ambiental dos Tipos de Configuração Morfológica}

Na região do Rio de Janeiro, o clima tropical, com altas temperaturas e elevada umidade, demanda determinadas condições para se evitar que a urbanização traga prejuízos ao ambiente e à população.

Nesse sentido, o suporte natural, o desenho urbano, no tocante ao traçado e à volumetria das edificações, e a massa de vegetaçāo cumprem um papel importante, ao estabelecer condições para que a drenagem, a radiação solar e a ventilação natural tenham melhor desempenho'.

(1) Segundo Marta Romero, nas regiōes tropicais de clima quente e úmido, o controle do desenho urbano deve observar a diminuição das temperaturas, que são elevadas sem variações diárias e de estação, aumentar o movimento do ar, evitar a absorção de umidade, proteger das chuvas e facilitar seu escoamento. Em ROMERO, Marta A. B. Princípios bioclimáticos para o desenho urbano, p.106-109. 
A relação com o suporte natural encontra-se definida em grande parte da cidade, em função de um processo, extenso, antigo e abrangente de urbanização. Sendo assim, as variáveis passíveis de intervenção, em relação à adequação ambiental, residem nas determinações quanto à morfologia do tecido, no tocante ao espaço privado, lotes e edificações, e ao espaço público, ruas, calçadas e praças. Essas determinaçōes devem observar a direção dos dominantes, as declividades existentes do terreno, a drenagem superficial do solo e as possibilidades do plantio vegetal.

Assim sendo, determinados tipos de configuração morfológica apresentam-se, de modo geral, mais favoráveis do que outros, do ponto de vista do perfil ambiental do Rio de Janeiro, como, por exemplo:

- o tecido urbano disperso, que permite, em relação à forma de urbanização e ao processamento do solo, aberturas intercaladas às edificaçōes e diferenças de gabaritos de construção, proporcionando maior ventilação das áreas construídas;

- as edificaçōes isoladas e circundadas por árvores e demais elementos vegetais, como espécies arbustivas e coberturas de forração, que, em regiões com densidade construtiva baixa, facilitam 0 sombreamento, a absorção de radiação e a permeabilidade do solo em relação à drenagem natural;

- a mescla de edifícios altos e baixos e o uso adequado de pilotis, nas regiões com densidade construtiva elevada, que favorecem a ventilação, por permitir melhor desempenho da circulação de ventos dominantes, evitando barreiras negativas, representadas por uniformidade de alturas, e bloqueios contínuos ao nível do chão;

- as quadras curtas, com ruas arborizadas, orientadas para a melhor insolação, que, somadas a elementos como marquises, galerias e alargamentos de trechos de calçadas, favorecem o conforto térmico dos pedestres;

- a ocupação dos lotes com alinhamentos e afastamentos variáveis para as edificaçōes, que auxilia a circulação do ar no interior das quadras e, somada à manutenção de superfícies gramadas, obtém melhor desempenho, no tocante à absorção e à reflexão de radiação solar;

- a grande quantidade e equilibrada distribuição de espaços livres, como praças, largos e jardins públicos, arborizados e com trechos em superfícies gramadas, que, intercalados a porções construídas do tecido urbano, propiciam a diminuição do calor, o diferencial térmico e a ventilação dos espaços construídos. 
Dentre os tipos de configuração morfológica, identificados para os subúrbios ferroviários da zona norte, alguns se conformam de modo mais adequado às condições ambientais do que outros, considerando-se os parâmentros gerais observados para cidade como um todo, além das condiçōes específicas relativas ao clima local, ao perfil topográfico, à drenagem superficial e à vegetação urbana.

Dessa forma, de modo geral, as quadras que apresentam maior incidência de "casas isoladas no lote" e "minipalacetes e chácaras", com quintais e jardins arborizados, são favoráveis ao clima, observando-se os aspectos relativos à implantação, à edificação e à arborização existentes.

Do mesmo modo, podem-se incluir, nessa situação, as quadras ocupadas por "prédios baixos", "edifícios modernos" com pilotis e "conjuntos habitacionais", de até quatro pavimentos, quando possuem afastamentos laterais, implantação adequada em relação à insolação e à direção de ventos, e incidência de farto plantio vegetal.

As "vilas residenciais" possibilitam melhores condições ambientais do que as "casas geminadas e correr de casas", devido ao espaço livre em seu interior, facilitando a ventilação cruzada para o interior da quadra. Quando são arborizadas, este tipo de implantação permite melhor condição de equilíbrio térmico.

As "torres isoladas no lote", com embasamento no nível térreo, quando de gabarito de altura elevado, ou seja, mais do que oito pavimentos, não são favoráveis ao clima local, uma vez que sua volumetria, geralmente com quatro fachadas expostas e sem proteção possível da arborização, leva à ocorrência de alta radiação, embora permita ventilação para o interior da quadra.

O embasamento, quando existente, impede a permeabilidade do solo e bloqueia a ventilação no nível do passeio, gerando desconforto ao pedestre. Quando de volumetria mais baixa e circundada por arborização, esse tipo de ocupação pode tornar-se mais oportuna.

As quadras com ocupação heterogênea, compostas por diversos tipos de implantação, indicam, normalmente, situações climáticas favoráveis, principalmente quando a relação entre as edificações apresenta-se adequada no tocante à ventilação, como, por exemplo, no caso da variação de alturas, de alinhamentos e de afastamentos e na ocorrência de plantio vegetal, dentro do espaço privado ou do espaço público. 
Em relação ao relevo e à drenagem superficial, a implantação dos subúrbios ferroviários apresenta condições desfavoráveis, de modo geral, pois toda a região é constituída por áreas baixas, que dificultam a drenagem. Além disso, muitas encostas se encontram desmatadas e ocupadas irregularmente, comprometendo a estabilidade do solo e a manutenção de rios e canais existentes.

No tocante à vegetação urbana, observa-se, nos bairros enfocados, pouca incidência de massa vegetal nos espaços públicos e privados, condição desfavorável à reflexão e absorção de radiação solar, aspecto importante para toda a região.

Os tipos de ocupação mais propícios, quanto à topografia, drenagem superficial e vegetação, são aqueles que permitem maiores índices de permeabilidade do solo, maiores afastamentos frontais e maior superfície de espaço livre interno ao lote, possibilitando calçadas e quintais arborizados. Podem-se incluir, nessas situações, "minipalacetes e chácaras urbanas", "casas isoladas", "prédios baixos" e "conjuntos habitacionais".

Os demais tipos, com elevada projeção de área construída e pavimentada ao nível térreo, não são adequados, pois além da impermeabilização do solo, dificultam o plantio. Nesses casos, incluem-se "torres isoladas", com embasamentos, "edifícios modernos", sem pilotis, "casas geminadas e correr de casas" e "vilas residenciais", sem jardins frontais e de fundos.

\section{Sugestões para a Melhor Qualidade da Paisagem e do Ambiente Urbanos}

Em face das análises realizadas a respeito da estrutura da paisagem dos subúrbios ferroviários da zona norte e de seus tipos de configuração morfológica característicos, foram reunidas algumas sugestões e recomendações no tocante a futuras modificações que esta região venha a sofrer, tanto em intervenções diretas no espaço urbano como por meio de revisões e/ou mudanças a serem realizadas na legislação urbanística e ambiental.

$\mathrm{Na}$ análise da legislação urbanística, percebe-se, de modo geral, a falta de diretrizes paisagísticas que levem a melhor adequação da estrutura urbana e das edificações ao clima quente e úmido de toda a cidade.

As condições ambientais observadas nos subúrbios indicam que, em termos de morfologia do tecido urbano, as soluções mais favoráveis são as relativas a volumes mais horizontais, com menor exposição de 
fachadas, orientados para as melhores situações de insolação e direção predominante de ventos.

Esse aspecto leva a menor incidência de radiação solar e, somado a afastamentos laterais e frontais, presença de marquises, pilotis, galerias e abundância de vegetação, pode resultar em melhores desempenhos climáticos do que os observados atualmente.

Outro aspecto importante é aquele que se refere às questões relacionadas à preservação da memória e da paisagem urbanas, como contribuição ao fortalecimento do patrimônio cultural dos subúrbios da zona norte.

Nesse sentido, torna-se significativa a permanência de tipos de configuração morfológica e estética arquitetônica característicos dessa região, como, por exemplo, a "arquitetura da ferrovia", as "vilas residenciais", as "casas geminadas e correr de casas", os "pequenos prédios" e, em alguns casos, os "conjuntos habitacionais" mais antigos.

Reveste-se de igual importância a preservação de perspectivas que favoreçam a visibilidade dos marcos referenciais da paisagem, como, por exemplo, as elevações montanhosas da região, assim como as edificações, monumentos e demais elementos construtivos e naturais, que contribuem para a caracterização do patrimônio cultural local.

Na zona norte, a preservação da memória e a valorização da paisagem apresentam-se urgentes, uma vez que, ao contrário do centro e da zona sul, a história de seus bairros é menos conhecida, estudada e valorizada. A falta de investimentos públicos reflete e aprofunda esse quadro, que se espera ver revertido, especialmente, após as obras e projetos urbanos realizados nesse final do século.

Em relação às possibilidades de transformação da paisagem, constata-se a necessidade de adequação das futuras modificaçōes urbanas às condições ambientais e culturais locais.

A adoção de modelos externos normalmente interferem com padrões existentes, adaptando-os a novas formas de ocupação e aproveitamento do solo urbano. Processos passados são visíveis devido à sua cristalização no espaço da cidade, sendo possível identificar, analisar e comparar os seus resultados à luz das diver136 sidades presentes nas diferentes escalas: no conjunto da cidade, nos seus setores, nos bairros e nas quadras. 
Em relação a modificações em curso, os resultados são apenas previsíveis, podendo-se estimar suas conseqüências. A partir da revisão dos padrões existentes e de sua adequabilidade ambiental e cultural, é possível propor alternativas de transformação que permitam a vinculação entre modelos urbanísticos e paisagísticos à qualidade do ambiente urbano.

No caso dos subúrbios ferroviários da zona norte do Rio, especial atenção deve ser dada à conexão direta com a Barra da Tijuca, via Linha Amarela, e às possíveis adaptações de modelos oriundos de outro setor urbano em processo acelerado de ocupação. Formas de parcelamento e de ocupação do solo, assim como hábitos de vida e consumo poderão impulsionar a adoção de modelos novos, adaptados à zona norte, cujos bairros com acesso direto à via expressa, como Méier, por exemplo, já experimentam um novo impulso imobiliário, fator coadjuvante no processo de mudança.

A seguir são apresentados blocos de recomendaçōes, cujos conteúdos estão inter-relacionados, buscando-se, dessa maneira, uma melhor integração entre as medidas sugeridas ${ }^{2}$.

\section{a) Desenho e Morfologia da Paisagem}

Os instrumentos disponíveis para modificações e melhorias no tocante ao desenho e à morfologia da paisagem dos subúrbios ferroviários devem basear-se, primeiramente, no favorecimento à horizontalidade e maior dispersão do tecido urbano, pela relação mais equilibrada entre a massa construída e os espaços livres.

Devem também ser considerados: a diversidade e disposição de gabaritos, afastamentos e alinhamentos em relação à direção de ventos e à insolação; a formação de massa arbórea abundante; a recuperação das encostas e manutenção dos cursos d'água, e a valorização da memória e do patrimônio cultural.

Em relação ao suporte físico, as recomendações se remetem à preservação das condiçōes de estabilidade física das encostas e dos cursos d'água, por meio de identificação de áreas non-aedificandi, consonantes com o estabelecimento das diretrizes existentes para a Serra dos Pretos Forros, indicada para "proteção ambiental", pelo Plano Diretor Decenal da Cidade, promulgado em 1992.

(2) As recomendações feitas para os subúrbios ferroviários incluem propostas indicadas em M\&T. Concurso o plano de estruturação urbana do Méier - relatório. 
Sugere-se também a identificação dos cones de visibilidade das elevações montanhosas existentes, buscando-se a presenvação dos panoramas, via controle de gabaritos e ocupação nos lotes, principalmente nas áreas localizadas nos entornos das elevações.

\section{Suporte legal}

A legislação urbanística e edilícia é um dos principais instrumentos para modificações no desenho da paisagem, a médio e longo prazo, interferindo com a utilização pública e privada do espaço, com as densidades construtivas, com os volumes edificados, com a incidência de espaços livres e com a valorização de elementos naturais, dentre esses, a vegetação urbana.

Como medidas legais, recomendam-se, de modo integral, a revisão de parâmetros de uso e ocupação do solo (índices de aproveitamento, taxas de ocupação, profundidades de construção, remembramentos e desmembramentos), visando a valorização dos tipos morfológicos adequados ao sistema ambiental local.

Sugere-se ainda a indicação de espaços livres destinados à recreação pública, pela identificação de áreas potenciais para esse fim, como, por exemplo, os terrenos atualmente utilizados para campos de futebol.

Outra medida necessária é a revisão dos Projetos de Alinhamento (P.A.'s), que poderá resultar na adequação das dimensões físicas de ruas e avenidas ao seu papel funcional no sistema viário e à sua melhor configuração paisagística, por meio do dimensionamento de passeios, da obrigatoriedade de arborização e do favorecimento à circulação de pedestres.

\section{Preservação de patrimônio}

As recomendações feitas em relação ao patrimônio cultural dos subúrbios visam reforçar a memória desses bairros, pela valorização dos tipos de morfologia, modelagem e estética da arquitetura e da paisagem locais, segundo medidas anteriormente previstas no Plano Diretor Decenal da Cidade ${ }^{3}$.

Nesse sentido, pode-se evitar a substituição de bens de interesse cultural, por meio da limitação dos índices de construção, e proceder à indicação de imóveis para tombamento.

(3) As recomendações incluídas em termos de patrimônio arquitetônico e cultural foram baseadas na pesquisa da arquiteta Dina Lerner, em M\&T. Concurso o plano de estruturação urbana do Méier - relatório. cap. II. 5.1 . 
Do mesmo modo, incluem-se, como recomendações, a definição de parâmetros urbanísticos específicos para novas edificações, no entorno de bens identificados e protegidos, e a recomendação de tipos edilícios compatíveis com entornos de bens e conjuntos históricos.

Pode-se ainda, como estímulo à recuperação e presenvação de imóveis, estabelecer incentivos fiscais e creditícios, tais como a isenção de impostos municipais ou a abertura de créditos de financiamentos, em moldes similares ao Projeto de Corredor Cultural, implantado na área central do Rio.

Em complementação às demais iniciativas, sugere-se a implantação de programas culturais, sociais e de animação urbana, que, ligados à questão da valorização do patrimônio cultural e arquitetônico, pela promoção do uso das edificações e espaços dos bairros, possam estimular práticas sociais tradicionais da comunidade ${ }^{4}$.

\section{b) Adequação Ambiental}

Do mesmo modo como são necessárias diretrizes normativas voltadas à adequação morfológica do tecido urbano, no tocante a conforto térmico, ventilação, permeabilidade do solo e vegetação, também se fazem necessárias, em face do complexo quadro ambiental dos subúrbios, determinações voltadas à preservação ambiental, a serem previstas na escala da região.

Nesse sentido, recomenda-se a indicação de áreas especiais de preservação ambiental, no mesmo molde das Unidades de Conservação, indicadas no Plano Diretor do Meio Ambiente do Município, elevando a quantidade de áreas livres e melhorando o equilíbrio entre a massa edificada e os espaços livres vegetados.

Sugere-se destinar, para esse fim, espaços existentes na região, que, além da preservação de recursos ambientais, atenderiam à demanda por áreas recreativas. Esses espaços incluem, dentre os mais importantes: a área da pedreira desativada, no pedágio da Linha Amarela, em Água Santa; a área do reservatório da Cedae e parte dos terrenos pertencentes ao complexo formado pelo Pátio das Oficinas, Museu dos Trens e Oficina de Pontes, da RFFSA, no Engenho de Dentro.

Esses novos espaços criados seriam objeto de diretrizes urbanísticas e paisagísticas, prevendo-se o uso do lazer e a ocupação com baixos índices de impermeabilização do solo.

(4) Como exemplo desse tipo de iniciativa pode ser apontado o Projeto da Lona Cultural de Realengo, na zona oeste da cidade. 
Além da criação de espaços, recomenda-se uma política de incentivos, fiscais e creditícios, a açōes particulares voltadas ao aumento da massa de vegetação urbana, tais como o reflorestamento das áreas de preservação existentes e a serem criadas, priorizando-se as encostas da Serra dos Pretos Forros, junto às cabeceiras dos cursos d'água, e a arborização das calçadas.

Como medida complementar, sugere-se a implantação de programas especiais de educação ambiental nas escolas da rede pública, enfatizando a valorização da vegetação urbana, o destino do lixo domiciliar e a preservação dos cursos d'água.

\section{c) Estudos e Pesquisas Complementares}

A ênfase nos aspectos formais e visuais é uma das formas qualitativas de análise da paisagem urbana, que não pode ser considerada exclusiva em conteúdo. Outros meios de estudo devem ser realizados em complementação, para que o quadro de resultados, conclusões e recomendações atinja níveis de complementariedade e interdisciplinariedade cada vez mais favoráveis.

No caso dos subúrbios ferroviários da zona norte do Rio, a caracterização do meio ambiente assume vital importância, podendo-se realizar estudos específicos no tocante às questões relativas ao conforto térmico e ambiental, em complementação às análises feitas para suporte físico, estabilidade de solos, drenagem natural e vegetação.

Do mesmo modo, percebe-se a necessidade de pesquisas e análises adicionais, no que diz respeito à percepção, apropriação, leitura e formação de imagem urbana dessa região pela população, fator de vital importância para a qualidade ambiental dos espaços, principalmente públicos, que configuram a memória coletiva da cidade pelos seus moradores.

Outras propostas podem relacionar-se diretamente a intervenções pontuais - arquitetônicas, paisagísticas e urbanísticas - que, se elaboradas de modo integrado aos contextos existentes, valorizando os aspectos de potencialidade paisagística e neutralizando os impactos ambientais negativos, certamente repercutirão positivamente no quadro da paisagem local e no orgulho da população local. 


\section{Bibliografia}

ARQUIVO M\&T. Pesquisa realizada para o Concurso Plano de Estruturação Urbana-PEU do Méier/ PMRJ - Arquivo fotográfico elaborado por Luiz Carlos Toledo, Dina Lerner e Vicente del Rio Coordenação M\&T-Mayerhofer \& Toledo - Arquitetura, Planejamento e Consultoria Ltda., 1995.

ARQUIVO PUZN. Arquivo fotográfico e iconográfico da pesquisa. Paisagem urbana na zona norte do Rio: As áreas livres públicas e seus arquétipos - registro SAG-UFRJ 3205 - Coordenação de Vera Regina Tângari - Pesquisadores: Marcos London e Gleice Alcino.

DGPC/SMAC. Série Olhos de Ver - Catete. Rio de Janeiro: PCRJ, 1996.

LERNER, Dina. Pesquisa sobre patrimônio cultural e arquitetônico. In: M\&T. Concurso o plano de estruturação urbana do Méier-relatório. Rio de Janeiro: M\&T, 1995. cap. II. 5.1.

M\&T. Mayerhofer, Toledo. Arquitetura, Planejamento e Consultoria Ltda. Concurso o plano de estruturação urbana do Méier - relatório. Rio de Janeiro: M\&T, 1995.

ROMERO, Marta A. B. Princípios bioclimáticos para o desenho urbano. São Paulo: Projeto, 1988.

SMU/PCRJ. Rio de Janeiro: Preservação e modernidade. Rio de Janeiro: Hambumg, 1998.

VAZ, Lilian. Uma história da habitação coletiva na cidade do Rio de Janeiro. São Paulo, 1994. Tese (Doutorado) - Faculdade de Arquitetura e Urbanismo, Universidade de São Paulo. 